\title{
Artikel
}

\section{Control of Relative Market Power in Competition Law}

\author{
An Instrument to Implement the Unfair Trading Practices Directive?
}

\author{
Jochen Glöckner*
}

On April 2019 the Directive on Unfair Trading Practices in business-to-business relationships in the agricultural and food supply chain has entered into force. In particular the remedies that the Member States are supposed to offer seem to be designed after the blueprint of competition law enforcement, and the practices deemed "unfair" in this Directive are closely related to abusive practices under Article 102 TFEU. While such practices are typically based on an economic dependence, no dominant position as required by Article 102 TFEU will be found. So, the question is whether an expansion of the scope of control of unilateral conduct under competition law might be the way to implement the Directive.

Germany has a long-standing tradition with respect to the expansion of the scope of control of abusive conduct to undertakings with less than a dominant position. Following a brief introduction that outlines the contents of the Directive (I.) this contribution is going to give a picture of the provisions on control of so-called "relative market power", i.e. a position of independence not versus all competitors and the opposite market side as defined by the ECJ, but only in the relation to individual trading partners under German competition law (II.), and finish with an outline of the structural problems that might stand in the way of implementing the new rules with a simple application or amendment of the

Prof. Dr. iur., J. Glöckner LL.M. (USA), Chair for German and European Private and Economic Law, Universität Konstanz; Judge at the Higher Regional Court Karlsruhe. competition law provisions on relative market power (III.)

\section{Introduction - Unfair Trading Practices and Competition law}

1. Directive on Unfair Trading Practices in the Agricultural and Food Supply Chain

a) Background

The plunge of milk prices in particular drew public attention to certain trade practices affecting the relationship between farmers, co-operatives, food producers and retail chains. ${ }^{1}$ Such practices are possible due to the lack of bargaining power of agricultural producers caused by various factors which typically result in a high degree of dependence of agricultural producers on retailers. $^{2}$

While one may be tempted to doubt this thesis based on the fact that the food production industry likewise has

1. European Commission, Communication from the Commission to the European Parliament, the Council, the European Economic and Social Committee and the Committee of the Regions of 07-15-2014, Tackling unfair trading practices in the business-to-business food supply chain, $\operatorname{COM}(2014) 472$ final.

2. Proposal of the Commission of 04-12-2018 for a Directive of the European Parliament and of the Council on unfair trading practices in business-to-business relationships in the food supply chain, COM (2018) 173 final, Explanatory Memorandum (hereinafter: Explanatory memorandum), p. 1. 
become increasingly concentrated with global players, ${ }^{3}$ it seems at least plausible that extra costs caused by unfair trading practices "are passed back along the food supply chain to the weakest link which is often the farmer". 4

The European Parliament's resolution of 7 June $2016^{5}$ made the European Commission work on a proposal for a Directive on unfair trading practices in business-tobusiness relationships in the food supply chain ${ }^{6}$ (Proposal, hereinafter: UTPD-P). On 31 April 2019 the Directive (EU) 2019/633 on unfair trading practices in business-to-business relationships in the agricultural and food supply chain (hereinafter: UTP Directive or $\mathrm{UTPD}^{7}$ entered into force. It has to be implemented by 1 May 2021.

\section{b) Contents}

The UTP-Directive requires the Member States to prohibit particular trading practices. Some forms of trading practices are considered to be unfair "as such" or "by their very nature" (consid. 16 s. 3 UTPD) while others remain subject to the parties' contractual discretion. ${ }^{8}$ The two kinds of unfair trading practices are distinguished by the two paragraphs of Article 3 UTPD. The Explanatory Memorandum of the Proposal and the considerations leave no doubt though that the distinction does not really depend on whether particular practices are particularly unfair because of their contents. Instead, the true rationale behind the distinction is based in Law and Economics: practices foreseen in clear and unambiguous terms in the supply agreement before the transaction are likely to generate efficiencies and therefore should not be prohibited. ${ }^{9}$ That is why their control is limited as opposed to practices that occur after the transaction has started without being agreed beforehand. ${ }^{10}$

The Proposal had limited the prohibitions to cases in which the trading practices had been used vis-à-vis a small or medium-sized undertakings pursuant to the Recommendation 2003/361 because SMEs were considered to be particularly vulnerable to such practices. ${ }^{11}$ Following severe criticism in the course of the legisla-

3. Just as an example, Nestlé reports a total yearly turnover of almost 80 bn EUR, Nestlé, Annual Review, p. 1, https://www.nestle.com/assetlibrary/documents/library/documents/annual_reports/2017-annualreview-en.pdf (last visited 20 August 2019)

4. Explanatory memorandum, p. 2.

5. European Parliament, resolution of 7 June 2016 on unfair trading practices in the food supply chain, P8_TA(2016)0250, para. 46.

6. Proposal of the Commission of 04-12-2018 for a Directive of the European Parliament and of the Council on unfair trading practices in business-to-business relationships in the food supply chain, COM (2018) 173 final.

7. Directive (EU) $2019 / 633$ of the European Parliament and of the Council of 17 April 2019 on unfair trading practices in business-to-business relationships in the agricultural and food supply chain, OJ 2019, L 111/59.

8. Explanatory memorandum, p. 9.

9. Ibid.; consid. 16 s. 1 UTPD.

10. Explanatory memorandum, p. 9; consid. 16 s. 2 UTPD.

11. Explanatory memorandum, p. 9 f., 13; consid. 7 s. 2, 3, Art. 1(2), Art. 2 let. c UTPD-P. tive proceedings ${ }^{12}$ a compromise was struck in Article 1(2) UTPD determining the personal scope of application based on the relative size of the supplier and the buyer in terms of annual turnover.

Article 3(2) UTPD prohibits particular practices unless they are previously agreed upon in clear and unambiguous terms. It concerns the return of unsold agricultural and food products to the supplier without payment (let. a), the charging of payments as a condition for the stocking, displaying or listing of agricultural or food products ("entrance fees", "shelf rents"; let. b), payments of the supplier for the promotion of agricultural and food products ("promotional contributions"; let. c) and payments of the supplier for the advertising and marketing of agricultural and food products (let. d, e, f). On the other hand, Article 3(1) UTPD prohibits another group of trading practices irrespective of whether they have been agreed upon: payment for perishable agricultural and food products later than 30 calendar days after the receipt of the invoice or delivery (let. a), the cancellation of orders of perishable agricultural and food products at overly short notice (let. b), unilateral changes of the terms of the supply agreement (let. c), demand of payments not related to the sale of agricultural and food products of the supplier (let. d), demand of payments of the supplier for wastage of food products occurring after the passing of risk to the buyer (let. e), the buyer's refusal to confirm in writing the terms of a supply agreement (let. f), the infringement of the supplier's trade secrets (let. g), the buyer's threat to retaliate against the supplier's exercise of contractual rights (let. h) and the buyer's demand of compensation for the cost of examining customer complaints (let. i).

From the very beginning of the discussion it was obvious that most, if not all, of the trading practices considered to be unfair were infringing on either general contract law or the binding force of the supply agreement. The remedies afforded by contract law, however, are generally not considered to be sufficiently effective as they have to be enforced by civil litigation. ${ }^{13}$ Suppliers with an inferior bargaining power thus may find themselves exposed to the risk of "winning their case, but losing their business". In shorthand this problem has been referred to as "fear factor". ${ }^{14}$ One of the main goals of the proposal was to provide remedies in order to help

12. E.g. Resolution of the Bundesrat, position taken on 8 June, BR-Drs. 116/18, para. 8; Centrum für Europäische Politik (cep), cepAnalyse no. 21/2018, p. 4. https://www.cep.eu/fileadmin/user_upload/cep.eu/ Analysen/COM_2018_173_Unlautere_Handelspraktiken/ cepAnalyse_COM_2018_173_Unlautere_Handelspraktiken.pdf (last visited on 20 August 2019); European Economic and Social Committee, Improving the food supply chain, opinion given by Peter Schmidt as rapporteur on 09-19-2018, NAT/734, para. 1.3, 4.5; AGRI committee of 10-10-2018, Draft European Parliament Legislative Resolution, Amendments 5, 14, 35, 88, A8-0309/2018.

13. European Commission, Communication from the Commission to the European Parliament, the Council, the European Economic and Social Committee and the Committee of the Regions of 07-15-2014, Tackling unfair trading practices in the business-to-business food supply chain, COM (2014) 472 final, p. 7.

14. Explanatory memorandum, p. 2. 
overcome this fear factor. ${ }^{15}$ Two instruments are foreseen to achieve this purpose: firstly, enforcement has to be granted by "enforcement authorities" pursuant to Article 4 UTPD. Secondly, Article 5 UTPD tries to offer confidentiality to the parties supplying the information necessary to enforce the law against infringing buyers in the course of complaints. The powers of the enforcement authorities as described in Article 6 UTPD are designed closely follow the pattern of the powers of competition authorities.

\section{Unfair Trading Practices in the Agricultural and Food Supply Chain and Competition Law}

In accordance with Article 42 TFEU, the provisions of the TFEU concerning competition apply to the production of and trade in agricultural products only to the extent determined by Union legislation within the framework of Article 43(2) TFEU. While the Regulation on a Common Market Organisation ${ }^{16}$ is based on this provision and contains specific provisions in Articles $206 \mathrm{ff}$., it is based on the assumption that the general rules of Articles 101-106 TFEU apply to all agreements, decisions and practices relating to the production of, or trade in, agricultural products. What is more, in its first report on the application of competition rules in the agricultural sector the Commission has shown that competition law can help farmers obtain better conditions when selling their products to large buyers. ${ }^{17}$

From the perspective of competition law the agricultural and food market presents itself structurally just like any other market. If it is reduced to three levels (agricultural producers, food producers, retailers) there is a vertical dimension of the market governed by contractual relationships: the "food supply chain" as addressed in the UTP Directive. However, a horizontal dimension remains, determined by the competitive relationships within the same levels of production, i.e. competition between agricultural producers, between food producers and between retailers. While market structures for food products may be particular in many ways, this fundamental structure underlies even the food market.

While the forms of conduct described by Article 3(2) UTPD can easily be conceived of as exploitative abuses - even the wording of Article 102 TFEU seems to have in mind such forms of abuse when it talks in let. a about "imposing unfair trading conditions" - the problem remains that on agricultural and food supply markets, as addressed in the UTP Directive, there will hardly be any dominance on the retail level as market dominance under Article 102 TFEU is typically defined as “a position of economic strength enjoyed by an undertaking which enables it to prevent effective competition being maintained on the relevant market by affording it the power to behave to an appreciable extent independently of its competitors, its customers and ultimately of the consumers." 18

This definition conveys the concept of "absolute" dominance, irrespective of direction (horizontal or vertical) and number of market participants (as suppliers, customers or competitors) or the existence of countervailing negotiating power. At this point, the market analysis becomes relevant: as long as there is effective competition on the retail level - and there certainly is on the agricultural and food retail markets throughout the Union - there is no independence of any single retailer and, consequently, no single market dominance.

The requirements of joint dominance, in particular the existence of structural links, ${ }^{19}$ are similarly not met. It must be ascertained whether economic links exist between those undertakings which enable them to act together independently of their competitors, their customers and consumers. ${ }^{20}$ Even on the most concentrated food retail markets this is not the case. Therefore, a considerable gap for cases without market dominance remains.

\section{Current Provisions on Control of Relative Market Power against Unilateral Abuses and Underlying Doctrine under German Competition Law}

At this point the gap of protection granted by competition law following the pattern of Articles 101 and 102 TFEU may be closed by an extension of particular prohibitions of unilateral conduct to undertakings with a less than dominant position. This has been done by German competition law since 1973 and continued even after the entry into force of Regulation No. $1 / 2003,{ }^{21}$ as Article 3(2)2 Reg. No. 1/2003 permits Member States to adopt and apply on their territory stricter national laws which prohibit or sanction unilateral conduct engaged in by undertakings. Today, this extension is laid down in sec. 20(1), (2) of the Act against Restraints
15. Ibid., p. 2, 10.

16. Regulation (EU) No. $1308 / 2013$ of the European Parliament and of the Council of 17 December 2013 establishing a common organisation of the markets in agricultural products and repealing Council Regulations (EEC) No. 922/72, (EEC) No. 234/79, (EC) No. 1037/2001 and (EC) No. 1234/2007, OJ 2013, L 347/671.

17. European Commission - Press release of 26 October 2018, Commission publishes report on application of competition rules in the agricultural sector, IP/18/6182.
18. ECJ, 13 February 1979, 85/76, Hoffmann-La Roche \& Co. AG v. Commission of the European Communities, 1979 ECR 461, para. 38.

19. ECJ, 27 April 1994, C-393/92, Almelo, 1994 ECR I-1508, para. 42.

20. ECJ, 16 March 2000, Joined Cases C-395, 396/96 P, Compagnie maritime belge SA, 2000 ECR I-1365, para. 39.

21. Council Regulation (EC) No. 1/2003 of 16 December 2002 on the implementation of the rules on competition laid down in Articles 81 and 82 of the Treaty, OJ 2003, L 1/1. 
of Competition (hereinafter: ARC) and relates to the specific prohibitions of sec. 19 ARC:

"Sec. 19 Prohibited Conduct of Dominant Undertakings ${ }^{22}$

1. The abuse of a dominant position by one or several undertakings is prohibited.

2. An abuse exists in particular if a dominant undertaking as a supplier or purchaser of a certain type of goods or commercial services

1. directly or indirectly impedes another undertaking in an unfair manner or directly or indirectly treats another undertaking differently from other undertakings without any objective justification; [...]

5. requests other undertakings to grant it advantages without any objective justification; in this regard particular account shall be taken of whether the other undertaking has been given plausible reasons for the request and whether the advantage requested is proportionate to the grounds for the request.

[...]

§ 20 Prohibited Conduct of Undertakings with Relative or Superior Market Power

1. $\S 19(1)$ in conjunction with paragraph 2 no. 1 shall also apply to undertakings and associations of undertakings to the extent that small or medium-sized enterprises as suppliers or purchasers of a certain type of goods or commercial services depend on them in such a way that sufficient and reasonable possibilities of switching to other undertakings do not exist (relative market power). A supplier of a certain type of goods or commercial services is presumed to depend on a purchaser within the meaning of sentence 1 if this supplier regularly grants to this purchaser, in addition to discounts customary in the trade or other remuneration, special benefits which are not granted to similar purchasers.

2. $\S 19(1)$ in conjunction with paragraph 2 no. 5 shall also apply to undertakings and associations of undertakings in relation to the undertakings which depend on them. [...]"

\section{Protective Purpose of the Control of Relative} Market Power in Vertical Relations

Even though the early political campaign in favour of general competition rules in the early $1950 \mathrm{~s}^{23}$ had always stressed that vigorous competition enforcement also helped small and medium-sized enterprises, the introduction of control of relative market power was never considered to be an instrument of individual protection of market participants. From the late 1960s on, it was considered to be a main purpose of competition law

22. Translation provided by the Language Service of the Bundeskartellamt in cooperation with Renate Tietjen. The English translation includes the amendments to the Act by Article 1 of the Act of 1 June 2017, BGBI. I, p. 1416. The full text is available http://www.gesetze-im-internet.de/ englisch_gwb/ (last accessed 20 March 2019).

23. Cf. the contemporary description in: "Der siebenjährige Krieg", in: Der SPIEGEL, 1957, no. 27, p. $17 \mathrm{ff}$.
- inspiring both merger control and the control of unilateral conduct - to "keep markets open". ${ }^{24}$

What is more, the German legislator never extended the general prohibition of exploitative abuses (today in sec. 19(2) no. 2 ARC) to undertakings with relative market power. The extension of the prohibitions of unfair impediment and discrimination by undertakings with relative market power thus has to be construed under a genuinely competition-oriented goal. ${ }^{25}$ This is even more so given that after 1976 businesses were granted protection against unfair contract terms stipulated by suppliers or buyers with superior bargaining power under the Act on General Terms and Conditions (in 2002 the provisions were relocated into secs. $305 \mathrm{ff}$. Civil Code).

Against this backdrop it is quite clear that courts reacted reluctantly when the provisions were invoked not to gain market access or to restore a level playing field, but rather to modify a possibly less-than-balanced contract. $^{26}$ The provisions on "tapping", today secs. 20(2), 19(2) no. 5 ARC, have always been considered to be border line cases that are hard to justify under a purely competition-oriented perspective. ${ }^{27}$

\section{Elements of Relative Market Power}

Relative market power is defined as a dependence of small or medium-sized enterprises as suppliers or purchasers of a certain type of goods or commercial services as a consequence of the lack of sufficient and reasonable possibilities of switching to other undertakings.

\section{a) Why Relative?}

The kind of market power defined in sec. 20(1), (2) $\mathrm{ARC}$ is relative in that it is not necessary that the undertaking can act independently from all of his competitors and customers respectively suppliers. It suffices that the critical amount of independence exists with regard to just one other undertaking.

\section{b) Market Definition?}

The provision on relative market power requires that undertakings "as suppliers or purchasers of a certain type of goods or commercial services" depend on them. This term has usually been interpreted as a circumscrip-

24. Draft of the Federal Government of 08-03-1973, Entwurf eines Zweiten Gesetzes zur Änderung des Gesetzes gegen Wettbewerbsbeschränkungen, BT-Drs. VI/2520, p. 15, 32; Draft of the Federal Government of 09-27-1978, Entwurf eines Vierten Gesetzes zur Änderung des Gesetzes gegen Wettbewerbsbeschränkungen, BT-Drs. 8/2136, p. 17.

25. Draft of the Federal Government of 08-03-1973, Entwurf eines Zweiten Gesetzes zur Änderung des Gesetzes gegen Wettbewerbsbeschränkungen, BT-Drs. VI/2520, p. 19; Draft of the fractions of SPD, FDP of 01-25-1973, Entwurf eines Zweiten Gesetzes zur Änderung des Gesetzes gegen Wettbewerbsbeschränkungen, BT-Drs. 7/76, p. 14; Draft of the Federal Government of 09-27-1978, Entwurf eines Vierten Gesetzes zur Änderung des Gesetzes gegen Wettbewerbsbeschränkungen, BTDrs. 8/2136, p. 21; Federal Supreme Court, 11-20-1975, KZR 1/75 Rossignol, NJW 1976, 801, 802; Markert, in: Immenga \& Mestmäcker, Wettbewerbsrecht, Vol. II pt. 1, 5th ed., 2014, sec. 20 para. 8.

26. Federal Supreme Court, 24 September 2002, KVR 8/01, Konditionenanpassung, WRP 2002, 1436, 1441; Higher Regional Court Düsseldorf, 18 November 2015, VI-Kart 6/14 (V), Edeka wedding rebates, WuW 2016, 23.

27. Mestmäcker, Der verwaltete Wettbewerb, 1984, p. 69 
tion of the necessity of a market definition just like in market dominance cases, even though in many instances it was considered necessary to limit the relevant product market to quality or luxury products. ${ }^{28}$

Today, it is not so clear whether or not there really is a need to define a relevant market besides the dependence test. A recent judgment of the Federal Supreme Court has left this question expressly open. ${ }^{29}$ In another case the Federal Supreme Court has obviously omitted this step of the analysis. ${ }^{30}$

\section{c) Dependence as Lack of Substitutes}

Economic dependence is described as a lack of sufficient and reasonable (ausreichende und zumutbare) possibilities of switching to other undertakings. Whether reasonable substitutes exist or not has to be assessed on the basis of the commercial viability for the potentially dependent undertaking. If the potentially dependent undertaking is a retailer the question has to be asked whether a loss of supply seriously affects its own competitiveness on the next market level. As in market dominance cases, any dependence of the potentially dependent buyer's customers is transformed to the potential buyer. ${ }^{31}$ It is considered unacceptable to change customers.

\section{d) Types of Dependence}

Since the creation of the original provision in sec. $26(2) 2$ ARC 1973 courts and doctrine have carved out the requirement of dependence in considerable detail.

\section{(1) Dependence Based on Choice}

\section{(sortimentsbegründete Abhängigkeit)}

Dependence may be based on the choice a retailer has to offer his own customers. If there is a producer of goods with a monopoly, there is clear-cut market dominance giving rise to a claim for supply for the retailer. If there is no monopoly, but a clear top position (Spitzenstellung) of one producer, relative market power is generally accepted. A top position exists if a producer enjoys a reputation due to the quality and exclusivity of his products and, consequently, has gained such a position on the market that the retailer as a buyer needs to carry these products, because their lack in his range of products would lead to a loss of reputation and to a serious challenge to his competitiveness. ${ }^{32}$

Whether or not such a form of dependence, based on choice, exists has to be assessed on the grounds of a

28. Federal Supreme Court, 26 June 1979, KZR 7/78, Revell Plastics, WuW/E BGH 1620, 1623; Markert, in: Immenga \& Mestmäcker, Wettbewerbsrecht, Vol. II pt. 1, 5th ed., 2014, sec. 20 para. 14; Loewenheim, in: Loewenheim, Meessen, Riesenkampff, Kersting \& MeyerLindemann, Kartellrecht, 3rd ed., 2016, sec. 20 para. 12.

29. Federal Supreme Court, 12 December 2017, KZR 50/15, Rillenkoffer, GRUR 2018, 441, at para. 15.

30. Federal Supreme Court, 6 Ocotober 2015, KZR 87/13, Porsche-Tuning, WRP 2016, 229, at para. 54

31. Federal Supreme Court, 26 January 2016, KZR 41/14, Jaguar-Vertragswerkstatt, NJW 2016, 2504, at para. 22 with further references; Federal Supreme Court, 23 January 2018, KZR 48/15, Jaguar/Land Rover, WuW 2018, 326, at para. 23.

32. As in the leading case Federal Supreme Court, 20 November 1975, KZR 1/75, Rossignol, NJW 1976, 801. Federal Supreme Court, 12 December 2017, KZR 50/15, Rillenkoffer, GRUR 2018, 441, at para. 16. comprehensive evaluation of all circumstances at hands. Excellent quality, unique technical design or exposed advertising may indicate a top position. ${ }^{33}$ High market shares may as well indicate a top position, ${ }^{34}$ but this is not necessarily so, typically not in the case of high-quality or luxury goods. Whether or not such a top position exists is best indicated by the distribution ratio. ${ }^{35}$ It goes without saying that the distribution ratio is less conclusive when the producer operates a selective distribution system. ${ }^{36}$ The courts extended this argument to undertakings that merely belong to a top group of producers, the range of products of which is expected to be carried by a serious retailer (Spitzengruppenzugehörigkeit). ${ }^{37}$

\section{(2) Dependence Based on the Undertaking} (unternehmensbedingte Abhängigkeit)

Dependence may also be caused by grounds in the potentially dependent undertaking itself and its business relationship. A distributor who has been specializing in products of one particular supplier over many years may not only have acquired special expertise in these products, but may also find it hard to sell and work on other products, making it difficult to substitute to distributing other products.

Consequently, economic dependence is generally accepted if a supplier or buyer of a certain type of goods or commercial services has adapted his commercial operations in the framework of long term - not necessarily ${ }^{38}$ contractual ${ }^{39}$ relations so much to an undertaking on the opposite market side that switching to other business partners is impossible without serious economic prejudice. ${ }^{40}$ Even a unilateral concentration of supply may induce a situation of economic dependence based on the undertaking. ${ }^{41}$ In such cases the fact that the undertaking with a relative market power is forced into this situation without any contribution of his own, except continuous supply over a period of time, will have to be

33. Federal Supreme Court, 12 December 2017, KZR 50/15, Rillenkoffer, GRUR 2018, 441, at para. 17.

34. Federal Supreme Court, 24 March 1981, KZR 2/80, SB-Verbrauchermarkt, WuW/E BGH 1793, 1795; Chamber Court, 4 February 1985, Kart 2/84, Märklin, WuW/E OLG 3501, 3502 (50\% market share indicating absolute dominance).

35. Federal Supreme Court, 9 May 2000, KZR 28/98, Designer-Polstermöbel, GRUR 2000, 1108, 1109; Federal Supreme Court, 12 December 2017, KZR 50/15, Rillenkoffer, GRUR 2018, 441, at para. 18.

36. Federal Supreme Court, 12 December 2017, KZR 50/15, Rillenkoffer, GRUR 2018, 441, at para. 19.

37. Since Federal Supreme Court, 17 January 1979, KZR 1/78, Fernsehgeräte I (Nordmende), WuW/E BGH 1667, 1669.

38. Federal Supreme Court, 6 October 2015, KZR 87/13, Porsche-Tuning, WRP 2016, 229, at para. 56.

39. Federal Supreme Court, 28 June 2005, KZR 26/04, Qualitative Selektion, WuW/E DE-R 1621, 1623, with further references.

40. Federal Supreme Court, 23 February 1988, KZR 20/86, Opel-Blitz, WuW/E BGH 2491, 2493; Federal Supreme Court, 21 February 1995, KZR 33/93, Kfz-Vertragshändler, WuW/E BGH2983, 2988; Federal Supreme Court, 28 June 2005, KZR 26/04, Qualitative Selektion, WuW/E DE-R 1621, 1623; Federal Supreme Court, 30 March 2011, KZR 6/09, MAN-Vertragswerkstatt, BGHZ 189, 94, at para. 26; Federal Supreme Court, 6 October 2015, KZR 87/13, Porsche-Tuning, NZKart 2015, 535, at para. 53 ff.; Federal Supreme Court, 26 January 2016, KZR 41/14 - Jaguar-Vertragswerkstatt, NJW 2016, 2504, at para. 28.

41. Federal Supreme Court, 6 October 2015, KZR 87/13, Porsche-Tuning, WRP 2016, 229, at para. 56. 
addressed under the question whether or not his conduct may be considered abusive. ${ }^{42}$

(3) Dependence Based on Scarcity (knappheitsbedingte Abhängigkeit)

Economic dependence may also be based on the scarcity of the products. The seminal case was provided during the first oil crisis when the vertically integrated fuel producers chose to supply only their own network of gas stations with car fuel, but refused to supply independent gas stations. $^{43}$

\section{(4) Dependence Based on Demand} (nachfragebedingte Abhängigkeit)

a. Product specialization

The first sub-group of dependence based on demand is characterized by the specialization of products. Mostly in the course of long-term contractual relations a supplier may produce goods that are specifically designed for the needs of single purchasers and cannot be marketed otherwise. Similarly, some producers do not appear on their products themselves; instead, they produce according to the specifications of an undertaking active in trade. The product or its packaging thus may be useful only for one particular buyer. Finally, products intended to be bought in particular by public bodies may, due to particular specifications, be marketable only to a very limited number of potential buyers.

The dependence based on product specialization may be compared to the dependence based on the undertaking in supply cases, ${ }^{44}$ in that the potentially dependent undertaking has actively contributed to its dependence by reducing the general marketability of its product range. As a general principle, the supplier has to carry the risks underlying such business decisions. Consequently, any dependence has to be limited by the time it takes to unwind the specialisation of products.

b. Retail Function

There may be situations in which a producer needs to participate in a particular distribution network due to its excellent reputation. Such a situation may exist if a retailer is known to distribute all quality products of a specific type of goods or his product portfolio shares a common quality feature. Supermarkets specializing in organic produce or otherwise eco-friendly goods may spring to mind.

More generally, dependence may exist if the purchaser is a wholesaler or a purchase centre with a gate keeper function or if the sales share of a supplier towards a single buyer is particularly high. The Federal Supreme Court found an optician dependent on a health insurer, because this health insurer paid for one third of all sales

42. Ibid

43. Cf. Unterrichtung des Ausschusses für Wirtschaft (9. Ausschuss) zu dem von den Fraktionen der SPD, FDP eingebrachten Entwurf eines Zweiten Gesetzes zur Änderung des Gesetzes gegen Wettbewerbsbeschränkungen - Drucksache 7/76 - Bericht der Abgeordneten Dr. Frerichs und Dr. Jens, BT-Drs. $7 / 765$, p. 10. One case made it to the courts, Chamber Court, 4 July 1974, Kart 27/74, Agip II, WuW/E OLG 1499, 1502.

44. Loewenheim, in: Loewenheim, Meessen, Riesenkampff, Kersting \& Meyer-Lindemann, Kartellrecht, 3rd ed., 2016, sec. 20 para. 35 of this optician. ${ }^{45}$ Scholars recommend to use a sales share of $10 \%$ as a rule of thumb for dependence based on the retail function of the buyer. ${ }^{46}$ In any case a detailed analysis of the facts is required. ${ }^{47}$ The Federal Supreme Court rejected an assumption of dependence at a sales share of $7.5 \% .{ }^{48}$ In the most recent case $W e d-$ ding rebates the Federal Supreme Court approved of relative market power based on demand due to the retail function at sales shares of more than $10 \%$. ${ }^{49}$

Dependence based on demand and caused by the retail function has to be assessed on the grounds of all properties of the market - not the general market for food products $e . g$., but the particular market for the individual products of the potentially dependent supplier. As a result, the sales share may not be conclusive for the dependence, because there is, for example, a different competitive situation or because the reputation of the product itself may lead to a dependence even of a retailer with high purchasing power. So even beyond a sales share of $10 \%$ the potentially dependent supplier may substitute to other forms of distribution. ${ }^{50}$ In the same vein the Federal Supreme Court has examined both the possibilities of the suppliers to broaden other paths of distribution and the countervailing bargaining power of the suppliers. With regard to the latter, the Federal Supreme Court has rightly noted that for a retailer with a full range of food products it may be easier to operate without any particular sparkling wine, but for the producer of sparkling wine it may be much more problematic to do business without this particular retailer. ${ }^{51}$

When dependence based on demand is caused by the retail function of the buyer, it cannot be put on equal footing with dependence based on the undertaking. ${ }^{52}$ In particular parallel behaviour of all buyers may seriously jeopardize the possibilities of the potentially dependent undertaking to switch to other buyers.

\section{e) Presumption of Dependence of Suppliers}

Pursuant to sec. 20(1)2 ARC, dependence is presumed if the supplier regularly grants to this purchaser, in addition to discounts customary in the trade or other remuneration, special benefits which are not granted to similar purchasers. The presumption comes to the help of the supplier though in that the supplier can fulfil his procedural onus by establishing that he had to regularly

45. Federal Supreme Court, 12 May 1976, KZR 14/75, Sehhilfen, WuW/E BGH 1423, 1425.

46. Markert, in: Immenga \& Mestmäcker, Wettbewerbsrecht, Vol. II pt. 1, 5th ed., 2014, sec. 20 para. 48

47. Loewenheim, in: Loewenheim, Meessen, Riesenkampff, Kersting \& Meyer-Lindemann, Kartellrecht, 3rd ed., 2016, sec. 20 para. 37

48. Federal Supreme Court, 24 September 2002, KVR 8/01, Konditionenanpassung, WRP 2002, 1436, 1440.

49. Federal Supreme Court, 23 January 2018, KVR 3/17, Hochzeitsrabatte I, WRP 2018, 556, para. 42

50. Federal Supreme Court, 24 September 2002, KVR 8/01, Konditionenanpassung, WRP 2002, 1436, 1440.

51. Federal Supreme Court, 23 January 2018, KVR 3/17, Hochzeitsrabatte I, WRP 2018, 556, para. 44 ff., 47

52. Federal Supreme Court, 24 September 2002, KVR 8/01, Konditionenanpassung, WRP 2002, 1436, 1440. 
grant special benefits. Then it is for the buyer to establish that there is no dependence.

\section{f) Protection against Discrimination and Unfair Impediment Limited to SME}

Even though the special protection afforded by sec. 20(1) ARC has been limited to SME ever since 1989, it is generally agreed that the quality of an SME is a function of its relative significance on a particular market. Absolute terms such as number of employees or turnover are irrelevant. ${ }^{53}$ The Federal Supreme Court found a decision of the Federal Cartel Office flawed in which the Federal Cartel Office had reasoned the quality of an SME only on the basis of turnover thresholds, but failed to assess the market situation.

Whether an enterprise is small or medium-sized has to be assessed in every single case on the basis of the facts, taking into consideration the peculiarities of the relevant market including the horizontal relationship to competitors with regard to customers and under particular circumstances also the vertical relationships to customers with countervailing buying power. ${ }^{54}$ More recently, the courts have indicated quite clearly that the quality of an inferior undertaking as SME is closely linked to the type of dependence (see supra): for dependence based on choice and demand it is considered crucial to compare the size of the inferior undertaking with that of its competitors. ${ }^{55}$ For dependence based on the undertaking the Federal Supreme Court has openly departed ${ }^{56}$ from the legislator's view and has found it more appropriate to compare sizes in a vertical direction. ${ }^{57}$

From 1989 on the prohibition of tapping by undertakings with relative market power was likewise limited to the protection of SME. The Act Combating Price Abuse of 2008 removed this limit.

\section{Protection Limited to Specific Forms of Abuse}

\section{a) Unfair Impediment or Discrimination, sec. 19(2) no. 1 ARC}

The principal forms of abusive conduct that may give rise to liability of an undertaking with relative market power are unfair impediment or discrimination, secs. 20(1), 19(2) no. 1 ARC. Unfair impediment and discrimination are typically read together. ${ }^{58}$ The fact

53. Draft of the Federal Government of 05-30-1989, Entwurf eines Fünften Gesetzes zur Änderung des Gesetzes gegen Wettbewerbsbeschränkungen, BT-Drs. 11/4610, p. 15 f., 22.

54. Federal Supreme Court, 24 September 2002, KVR 8/01, Konditionenanpassung, WRP 2002, 1436, 1439.

55. Federal Supreme Court, 19 January 1993, KVR 25/91, Herstellerleasing, WuW/E BGH 2875, 2878; Federal Supreme Court, 24 September 2002, KVR 8/01, Konditionenanpassung, WRP 2002, 1436, 1439 f.; Federal Supreme Court, 12 December 2017, KZR 50/15, Rillenkoffer, GRUR 2018, 441, at para. 13.

56. Loewenheim, in: Loewenheim, Meessen, Riesenkampff, Kersting \& Meyer-Lindemann, Kartellrecht, 3rd ed., 2016, § 20 para. 10.

57. Federal Supreme Court, 19 January 1993, KVR 25/91, Herstellerleasing, WuW/E BGH 2875, 2879; Federal Supreme Court, 6 June 2015, KZR 87/13, Porsche-Tuning, WRP 2016, 229, at para. 58.

58. Markert, in: Immenga \& Mestmäcker, Wettbewerbsrecht, Vol. II pt. 1, 5th ed., 2014, sec. 19 para. 101 with further references. that one absolutely or relatively powerful undertaking contributes to distorting competitive relationships on a neighbouring market is sufficient to warrant the application of competition law. ${ }^{59}$ On the other hand, it is necessary that the competitiveness of the undertaking that suffers from impediment or discrimination on its own sales market is diminished. Pure exploitation of the supplier or buyer is not sufficient. ${ }^{60}$

From the very beginning of the fact pattern it was used to grant retailers access to goods. When in the course of the Second Amendment of the ARC in 1973 the legislator did away with the permission of resale price maintenance of trade marked goods pursuant to sec. 16 no. 1 ARC $1958,{ }^{61}$ it was feared that the producers of trademarked goods would resume to unilateral pressure on distributors to maintain their price levels. Hence the scope of application of the provisions controlling unilateral conduct was expanded. ${ }^{62}$ The second - then very topical - issue arose from the experiences made during the first oil crisis when vertically integrated producers of fuel would supply only their own networks of gas stations, but would cut off independent operators of gas stations. ${ }^{63}$

\section{b) Demand of Advantages without Objective Fustification, sec. 19(2) no. 5 ARC}

\section{(1) Origins}

While the origins of the control of relative market power were closely connected with the superior bargaining position of producers of goods marketed under wellknown trademarks versus retailers, it became clear in the following years that the game was changing. Supermarket chain stores grew; retail market concentration started and smaller corner shops were driven out of the market. This was all accompanied by trading practices in which the supermarket chain stores made use of their purchasing power by squeezing their suppliers, typically in the guise of asking for side performances (Nebenleistungswettbemerb) instead of exercising direct price pressure. The famous "list of sins" issued by the German Ministry of Economics ${ }^{64}$ in 1974 and the Joint Declaration of the Organizations of the Commercial Economy to Maintain Competition on the Merits ${ }^{65}$ of 1976 did not remain unheard. Trading practices relating to

59. Ibid., sec. 19 para. 96 .

60. Ibid., sec. 19 para. 103

61. Art. 1 no. 6 Zweites Gesetz zur Änderung des Gesetzes gegen Wettbewerbsbeschränkungen. Vom 3. August 1973, BGBI. I, p. 917

62. Unterrichtung des Ausschusses für Wirtschaft (9. Ausschuss) zu dem von den Fraktionen der SPD, FDP eingebrachten Entwurf eines Zweiten Gesetzes zur Änderung des Gesetzes gegen Wettbewerbsbeschränkungen - Drucksache 7/76 - Bericht der Abgeordneten Dr. Frerichs und Dr. Jens, BT-Drs. 7/765, p. 9

63. Ibid., p. 10

64. "List of Sins", Federal Ministry of Economics of 15 November 1974 (Beispielskatalog von Tatbeständen, die zu Wettbewerbsverzerrungen führen können, Bundeswirtschaftsministerium, 15. November 1974), WRP 1975, 24.

65. Safeguarding Protection on the Merits, Joint Declaration of Organizations of the Commercial Economy (Sicherung des Leistungswettbewerbs, Gemeinsame Erklärung von Organisationen der gewerblichen Wirtschaft), WuW 1976, 17 
"industrial fringe benefits" demanded by retailers from suppliers, ${ }^{66}$ e.g. "entrance fees", "listing fees", "shelf rental fees", "shop window rental fees", "promotion fees", "special rebates" for given occasions etc. were addressed under the figurative term "tapping" (in German: anzapfen) relating to the picture of hitting a tap into a barrel to gain unlimited access to its resources.

A new prohibition of "tapping" was founded on the fact that the undertaking with relative market power gained a competitive advantage with regard to its own competitors ("passive discrimination"), but the general prohibition of discrimination was not applicable. ${ }^{67}$ This prohibition has remained in force until today in sec. 19(2) no. 5 ARC and its scope of application has covered undertakings with relative market power, as governed today by sec. 20(2) ARC. An assumption of economic dependence was added, ${ }^{68}$ triggered by the granting of unusual benefits going beyond typical rebates or prices.

In 1989 the level of protection was lowered in that large enterprises - as opposed to small and medium-sized enterprises - were no longer afforded protection vis-àvis undertakings with relative market power. ${ }^{69}$ In particular, a de facto duty to contract was considered to be an overly deep intrusion into the freedom of contract to be justified in respect of large enterprises. Large enterprises typically did not need the extra protection against the abuse of a superior bargaining position. ${ }^{70}$ With regard to the terms "small and medium-sized" as opposed to "large", the Government's explanatory memorandum makes clear that absolute criteria of size are irrelevant. Instead, the relations of size on the same market level are critical. ${ }^{71}$

\section{(2) Tapping and Protection of Competition}

The prohibition in sec. 19(2) no. 5 ARC was initially referred to as "passive discrimination" caused by an abuse of purchasing power. The prohibition of discriminations in sec. 19(2) no. 1 ARC is not applicable, because the dominant undertaking that demands "special treatment" from his contract partners does not discriminate against this partner. ${ }^{72}$ The theory of harm underlying sec. 19(2) no. 5 ARC is based on the additional competitive advantage that the dominant under-

66. Draft of the Federal Government of 09-27-1978, Entwurf eines Vierten Gesetzes zur Änderung des Gesetzes gegen Wettbewerbsbeschränkungen, BT-Drs. 8/2136, p. 25.

67. Ibid., p. $24 \mathrm{f}$

68. Initially only for administrative proceedings, Draft of the Federal Government of 27 September 1978, Entwurf eines Vierten Gesetzes zur Änderung des Gesetzes gegen Wettbewerbsbeschränkungen, BT-Drs. $8 / 2136$, p. 24 , in the course of the fifth amendment also for civil proceedings, Draft of the Federal Government of 30 May 1989, Entwurf eines Fünften Gesetzes zur Änderung des Gesetzes gegen Wettbewerbsbeschränkungen, BT-Drs. 11/4610, p. 22

69. Art. 1 no. 8 let. a Fünftes Gesetz zur Änderung des Gesetzes gegen Wettbewerbsbeschränkungen. Vom 26. April 1980, BGBI. I, p. 458.

70. Draft of the Federal Government of 30 May1989, Entwurf eines Fünften Gesetzes zur Änderung des Gesetzes gegen Wettbewerbsbeschränkungen, BT-Drs. 11/4610, p. 22.

71. Ibid., p. 16

72. Draft of the Federal Government of 09-27-1978, Entwurf eines Vierten Gesetzes zur Änderung des Gesetzes gegen Wettbewerbsbeschränkungen, BT-Drs. 8/2136, p. 16. taking receives with regard to its own competitors as a consequence of its already existing dominant position. The legislator found it appropriate to sharpen the prohibition of exclusionary conduct pursuant to sec. 19(1), (2) no. 1 ARC, as it was by no means clear that an advantage gained by the dominant undertaking amounted to an anticompetitive exclusionary practice in respect of its competitors.

It is obvious though that the undertakings that would otherwise be prejudiced by such "passive discriminations" benefit in a mediate manner. Ultimately, it might be said, they could just as well be victimized by the dominant undertaking's "hard bargaining" directed at lower purchasing prices. Nevertheless, the doctrinal approach distinguishes the protection against tapping offered by sec. 19(2) no. 5 from the protection against exploitative abuses offered by sec. 19(2) no. 2 ARC. $^{73}$

In the past, the provision against tapping had not been very effective. ${ }^{74}$ The Bundeskartellamt intended to resurrect the provision in its proceedings against EDEKA for the demand of so-called wedding rebates from suppliers following their acquisition of over 2,300 "Plus" discount supermarkets from Tengelmann in 2008. ${ }^{75}$ However, the Higher Regional Court struck down the decision taken by Bundeskartellamt that had found an infringement of sec. 20(3) ARC 1998 (now Art. 19(2) no. 5, 20(2) ARC. The Higher Regional Court argued that the demand of such wedding rebates was not due to the (relative) market power of the dominant undertaking, but occurred in the course of ordinary negotiations. Use of market power had to be causal for specific advantages of the dominant undertaking. On appeal-on-law the Federal Supreme Court quashed the Higher Regional Court's judgment.

In doing so, it departed very openly from the theory of harm as presented above: in the view of the Federal Supreme Court the term "advantage" does not require any promotion of the dominant undertaking as opposed to its competitors. ${ }^{76}$ While the Court left open whether the provision in its original shape was intended to protect only competition on the level of the undertaking with relative market power, ${ }^{77}$ it relied on the amendment brought about by the Act Combating Price Abuses in 2008 to argue a twofold protective purpose in both competition on the level of the undertaking with relative market power on one hand and protection of suppliers in the vertical dimension on the other. ${ }^{78}$ In the same vein, it might be added, the Federal Supreme Court had already shifted its perspective when assessing the quality

73. Markert, in: Immenga \& Mestmäcker, Wettbewerbsrecht, Vol. II pt. 1, 5th ed., 2014, sec. 19 para. 368; Säcker \& Mohr, Forderung und Durchsetzung ungerechtfertigter Vorteile, WRP 2010, 1, 2; Möschel, Recht der Wettbewerbsbeschränkungen, 1983, sec. 10 paras. 660, $662 \mathrm{f}$.

74. Markert, in: Immenga \& Mestmäcker, Wettbewerbsrecht, Vol. II pt. 1, 5th ed., 2014, sec. 19 para. 366.

75. Reported by the Higher Regional Court Düsseldorf, 1 November 2015, VI-Kart 6/14 (V), Hochzeitsrabatte, WuW 2016, 23, at juris-para. 125.

76. Federal Supreme Court, 23 January 2018, KVR 3/17, Hochzeitsrabatte I, WRP 2018, 556, para. 54.

77. Ibid., para. 55 .

78. Ibid., para. 57. 
of an SME from the horizontal level towards own competitors in cases of dependence based on choice to the vertical level in cases of dependence based on the undertaking. ${ }^{79}$

Even before this judgment the German legislator had reacted: citing the Higher Regional Court's EDEKA judgment ${ }^{80}$ the Ninth Amendment of the Act against Restraints of Competition in 2017 made it clear that the simple demand of any undue advantage was sufficient and no specific causal nexus between the relative dominance and the particular contractual agreement had to be established. ${ }^{81}$ Moreover, the test of the negative requirement "without objective justification" was simplified by adding the requirement that reasons for the additional advantage be given.

\section{Law in Action}

The brief summary of the development and current interpretation of the rules relating to the control of unilateral conduct of undertakings with relative market power under German competition Law have shown that the main provisions have not lead a miserable existence as forgotten law in the books. Not only do commentaries fill hundreds of paragraphs of annotations, but a substantial body of case law has evolved. The most comprehensive German database shows 84 hits for Court decisions on sec. 20 ARC just from 2014 to 2019. Most cases are brought as civil cases, but the competition authorities, in particular the Bundeskartellamt, have likewise delved into the exploration of the underlying concepts.

At the bottom line, the application of the prohibitions of unfair impediment and discrimination for undertakings with only relative market power based on choice, based on the undertaking or based on scarcity rounds off the standard fact patterns of competition law in a very positive manner. In the past the concept of relative market power has helped most notably specialized brick-andmortar trade to get access to the market, thus enhancing competition on the distribution level and improving choice for consumers.

Things are more differentiated when it comes to relative market power based on demand, and more particularly, due to the retail function, in combination with the prohibition of "tapping". Even with almost 40 years of experience there is only little case law - mostly enshrined in the Federal Supreme Court's judgments Adaptation of conditions (2002) and Wedding rebates (2018). Yet, chances are that with the recent cases and the reform of black letter law the fact pattern may face a late career: in the age of electronic commerce the pro-

79. Federal Supreme Court, 19 January 1993, KVR 25/91, Herstellerleasing, WuW/E BGH 2875, 2879; Federal Supreme Court, 6 October 2015, KZR 87/13, Porsche-Tuning, WRP 2016, 229, at para. 58.

80. Government's proposal for a Ninth act amending the Act against Restraints of Competition (Entwurf eines Neunten Gesetzes zur Änderung des Gesetzes gegen Wettbewerbsbeschränkungen), BT-Drs. 18/10207, p. 52.

81. Draft of the Federal Government of 7 November 2016, Entwurf eines Neunten Gesetzes zur Änderung des Gesetzes gegen Wettbewerbsbeschränkungen, BT-Drs. 18/10207, p. 52. hibitions will come to the help of small traders using online sales platforms. ${ }^{82}$

5. Summary: The Application of the Rules on Relative Market Power in the Framework of German Competition Law

While it is obvious that the existence of relative market power has to be ascertained in every single relationship and may result in different outcomes for different products, even within the same business relationship, ${ }^{83}$ the legal concept of "relative market power" itself does not seem to be more problematic to apply than the concept of absolute market dominance.

This being said, the extension of protection afforded by sec. 20 ARC is limited to specific forms of abuse, most notably forms of exclusionary abuse and discrimination as governed by sec. 20(1) ARC. In cases of unfair impediment and discrimination, as governed by secs. 20(1), 19(2) no. 1 ARC, a horizontal relation, namely the relation between the dependent undertaking and its competitors, is protected.

The more courts and the legislator have been ready to make use of the fact pattern in secs. 20(2), 19(2) no. 5 ARC to protect suppliers in a vertical relationship, the further the scope of application of the Act against Restraints of Competition is shifting away from its original purpose to protect competition as a process. The original legislator was well aware of this problem and expressed a theory of harm based on the competitive relationship between the undertaking with relative market power and its competitors. Yet, only the Federal Court of Justice was frank enough to admit that protection of market participants in itself was an independent goal justifying the application.

From a constructivist perspective, there can hardly be an argument against such interpretation as the original provisions are well over 40 years old, societal needs have changed, the legislator has obviously followed a different track in recent years and the courts have clearly expressed their opinion. The one argument that can be put forward against such an extension is that protection of individual competitors going beyond the protection

82. In this respect cf. Communication from the Commission to the European Parliament, the Council, the European Economic and Social Committee and the Committee of the Regions of 05-25-2016, Online Platforms and the Digital Single Market. Opportunities and Challenges for Europe, COM[2016] 288 final; European Commission, Press release IP/19/1168 of 14 February 2019, Digital Single Market: EU negotiators agree to set up new European rules to improve fairness of online platforms' trading practices. In parallel the EU Commission has started investigations with regard to trading practices of Amazon, Business Insider of 19 September 2018, The EU is now going after Amazon after slapping Google and Apple with giant fines, https://www.businessinsider.de/amazoninvestigated-by-eu-commissioner-margrethe-vestager-2018-9? $r=U S \& I R=T$ (last accessed on 11 May 2019); the German Bundeskartellamt has initiated proceedings against Amazon investigating abusive conduct on its marketplace, Bundeskartellamt, Press release of 29 November 2018.

83. Cf. Federal Supreme Court, 24 September 2002, KVR 8/01, Konditionenanpassung, WRP 2002, 1436, 1439; Loewenheim, in: Loewenheim, Meessen, Riesenkampff, Kersting \& Meyer-Lindemann, Kartellrecht, 3rd ed., 2016, § 20 GWB para. $13 \mathrm{ff}$. 
that is afforded by unrestrained and undistorted competition has nothing to do with competition law.

\section{Implementation of the UTP Directive in the Framework of Competition Law?}

Getting back to the initial question whether the UTP Directive should be implemented by amending competition law - or maybe is even already implemented - the obvious proximity between the "unfair trading practices" governed by the UTP Directive and the provisions on relative market power relating to "tapping" in German Competition law is striking: the new rules react to an economic dependence and the lack of bargaining power that would typically form the basis of relative market power under sec. 20 ARC. What is more, the German provisions on "tapping" in sec. 19(2) no. 5 ARC owe their existence to business conduct of large retailers applying their purchasing power upstream towards their suppliers and asking for "fringe benefits" such as entrance fees, shelf rents, contributions to advertising, sales promotions and the like that emerged during the 1960s and 1970s. Thus, the best part of Article 3 UTPD appears like a 2018 remake of a 1978 movie. This begs the question whether competition law is the first choice for an implementation of the UTP Directive, in particular as the features of competition law enforcement inspire great confidence.

Some of the institutional experience accumulated in Germany for over almost 40 years may help answer this question. Firstly, the mystical term of "relative market power" has lost much of its deterrent effect: the concept behind it has developed clear contours At the end of the day the concept is not harder to apply for authorities, courts and undertakings than the concept of a dominant position. This must have escaped the European legislator though. Despite the wide-spread criticism of the simplistic definition of the scope of application in the original proposal and all urges to switch to a requirement of economic dependence, ${ }^{84}$ the European legislator has only abandoned the very weak proxy of SME versus non-SME in Article 1(2) UTPD-P for another expressly acknowledged proxy ("a suitable approximation for relative bargaining power", consid. 14 s. 2 UTPD), to wit the relation of turnover figures in Article 1(2) UTPD. From a competition perspective, this regulatory approach may lead to a considerable number of false negatives as well as false positives - many forms of anticompetitive conduct will not be caught by the provision while many forms of innocent or efficiency-enhancing conduct will be prohibited. However, as a consequence of the minimum harmonization requirement Article 1(2) UTPD would have to be implemented quasi-literally, producing an element alien to established principles of competition law.

Adding that to the fundamental problem of protecting against "vertical abuses" it becomes clear that, while competition law equipped with extended control of undertakings with relative market power might have been an adequate tool to combat unfair trading practices, the particular way the UTP Directive requires this is not foreseen on the map of competition law.

This relates both to the limited scope of application - while the German concept of relative market power is applied in any and all markets, the UTP Directive applies only to the markets within the agricultural and food supply chain - and the particular fact patterns in Article 3 UTPD. Consequently, it seems more appropriate not to implement the substantive provisions of the UTP Directive in competition law. Notwithstanding this, it may be appropriate to make use of the procedural infrastructure of competition law to enforce rules that go beyond the generally accepted scope of competition law. 